\title{
GEOHYDROLOGICAL STUDIES FOR NUCLEAR WASTE ISOLATION AT THE HANFORD RESERVATION \\ Volume I: Executive Summary
}

J. Apps, T. Doe, B. Doty, S. Doty, R. Galbraith, A. Kearns, B. Kohrt, J. Long, A. Monroe,

T. N. Narasimhan, P. Nelson, C. R. Wilson, and P. A. Witherspoon

\section{TWO-WEEK LOAN COPY}

\section{This is a Library Círculating Copy}

which may be borrowed for two weeks.

For a personal retention copy, call

\section{Tech. Info. Division, Ext. 6782}

August, 1979

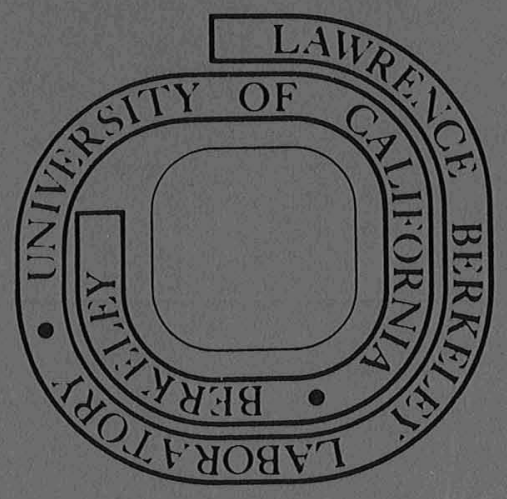

Prepared for the U. S. Department of Energy under Contract No. W-7405-ENG-48 and for Rockwell Hanford OperationsA Department of Energy Prime Contractor-under Memorandum Order No. W8A-SSB-51760. 
Lawrence Berkeley Laboratory Library

University of California, Berkeley 
GEOHYDROLOGICAL STUDIES FOR NUCLEAR WASTE ISOLATION

AT THE HANFORD RESERVATION

Volume I: Executive Summary

J. Apps, T. Doe, B. Doty, S. Doty, R. Galbraith, A. Kearns, B. Kohrt, J. Long, A. Monroe,

T. N. Narasimhan, P. Nelson, C. R. Wilson, and

P. A. Witherspoon

Earth Sciences Division

Lawrence Berkeley Laboratory

University of California

Berkeley, California 947.20

August 1979

Prepared for the U. S. Department of Energy under Contract No. W-7405-ENG-48 and for Rockwell Hanford Operations-a Department of Energy prime contractorunder Memorandum Order No. W8A-SBB-51760. 
|

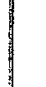
$r^{-2}$ 


\section{CONTENTS}

List of Figures

Page

I. Introduction

II. FY-1978 Accomplishments

A. Hydrology Field Program

1. Equipment Development

2. Field Test Results

B. Pasco Basin Modeling

1. Literature Survey for Regional Flow System

2. Recommended We11 Drilling and Testing Program

3. Wellbore Storage Effects

C. Groundwater Chemistry Program

1. Introduction

2. Previous Groundwater Chemistry Studies

3. 1978 Activities

4. Conclusions and Recommendations

D. Review of Hanford We11 Logs 


\section{LIST OF FIGURES}

1. Location map of the Columbia River basalt (after Rockwel1, 1977)

2. The Pasco Basin . . 4

3. Pressure measurements in wells $\mathrm{DC}-1$ and $\mathrm{DC}-2$

4. Water heads, flow rates, and permeabilities in well $\mathrm{DC}-6$

5. Summary of pressure measurements 9

6. Proposed first stage wells

7. Drawdown in an observation well with wellbore storage in the pumping well

8. Ratio of drawdown in the aquitard to drawdown in the aquifer

9. Drawdown as a function of time $\quad 18$

10. Four porosity-type logs in well DC-1 24

11. Summary figure of anomalous flow zones in well DC-1 


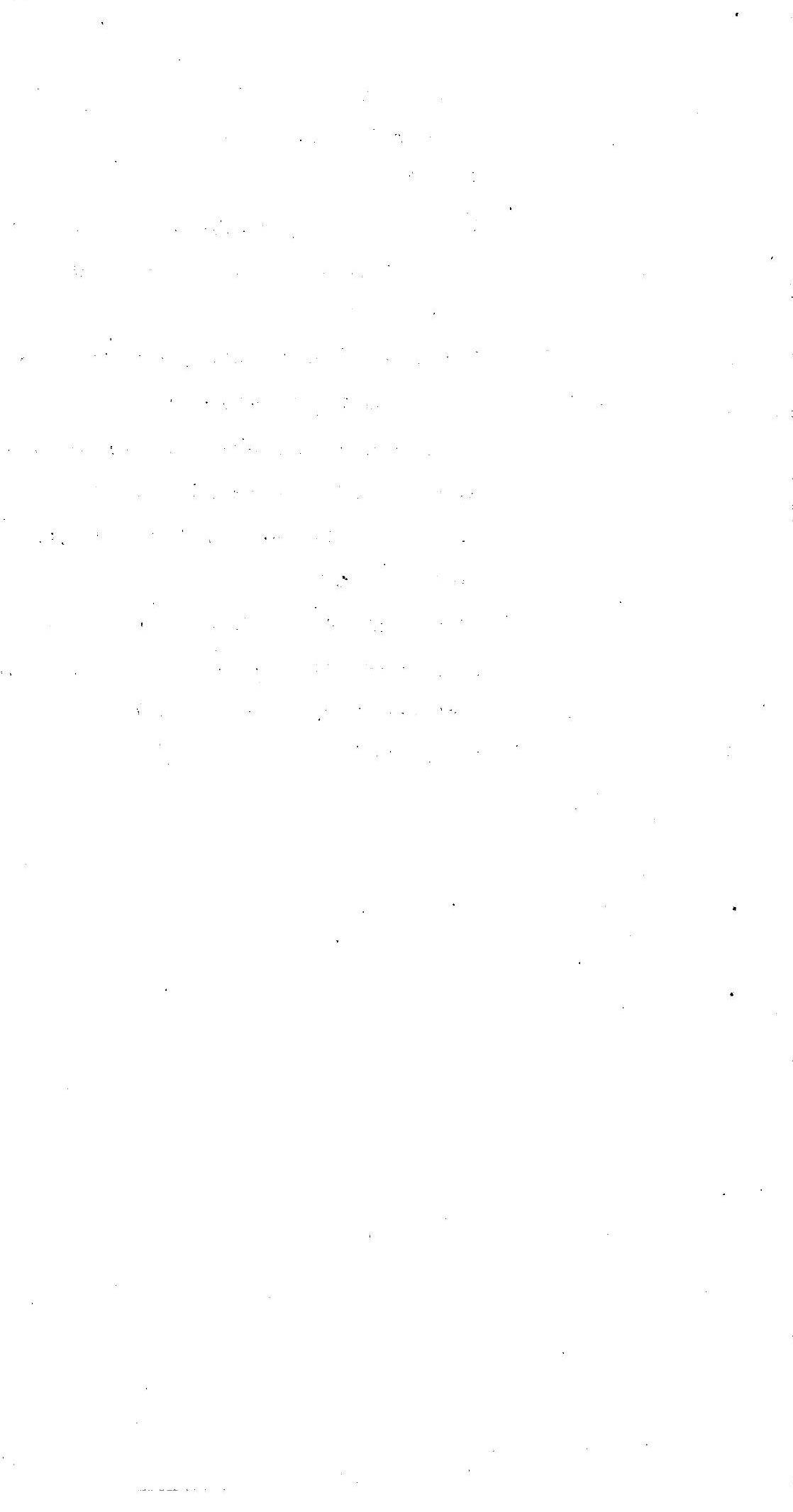




\section{INTRODUCTION}

A study of the hydrology of the Pasco Basin near Richland, Washington, was initiated by Lawrence Berkeley Laboratory for Rockwe11 Hanford Operations (Rockwe11) during Fiscal Year 1978. This work was part of a 1 ong-term feasibility study conducted by Rockwell's Basalt Waste Isolation Program for the National Waste Terminal Storage Program of the Department of Energy on the feasibility of nuclear waste disposal in the Columbia River Basalt underlying the Hanford Reservation.

The Hanford Reservation lies within the Pasco Basin near the center of the Columbia River flood basalt physiographic province, which spans parts of Washington, Oregon, and Idaho (Figure 1). The overall feasibility study has been directed to the concept of a mined repository at a depth of about 3000 feet, possibly in the Umtanum Unit, a dense 200 foot thick basalt f1ow. The feasibility of this concept largely depends on the degree of hydrologic isolation afforded by the basalts. Hydrologic isolation can be determined only by actual field testing and subsequent modeling.

In October 1977 a work plan was formulated which included three hydrologic subtasks: Physical Testing, Geochemical Sampling, and Numerical Modeling. Progress on these three subtasks through September 1978 is reported in this section. In addition to these subtasks an analysis of existing geophysical data is summarized here. Hydrologic work by LBL ceased at the end of FY 1978.

A physical testing program designed to provide hydrologic information for mathematical modeling of the deep basalts in the Pasco Basin was initiated in FY 1978. LBL performed hydrologic testing on several deep drill holes on the Reservation and obtained and analyzed water samples from drill holes and surface water. A technical approach was developed for obtaining and integrating the hydrological, geophysical, and geochemical data required for modeling. A field program oriented toward the collection of needed data was then initiated. A full hydrology testing program was planned for implementation over a period of several years. Included in this program were: pressure measurements to determine hydraulic potential gradients; tracer tests to determine flow direction and velocity; borehole fracture logging to quantify the geometric parameters of the fracture systems; hydraulic fracturing to determine in-situ stress conditions; a wide variety of permeability 


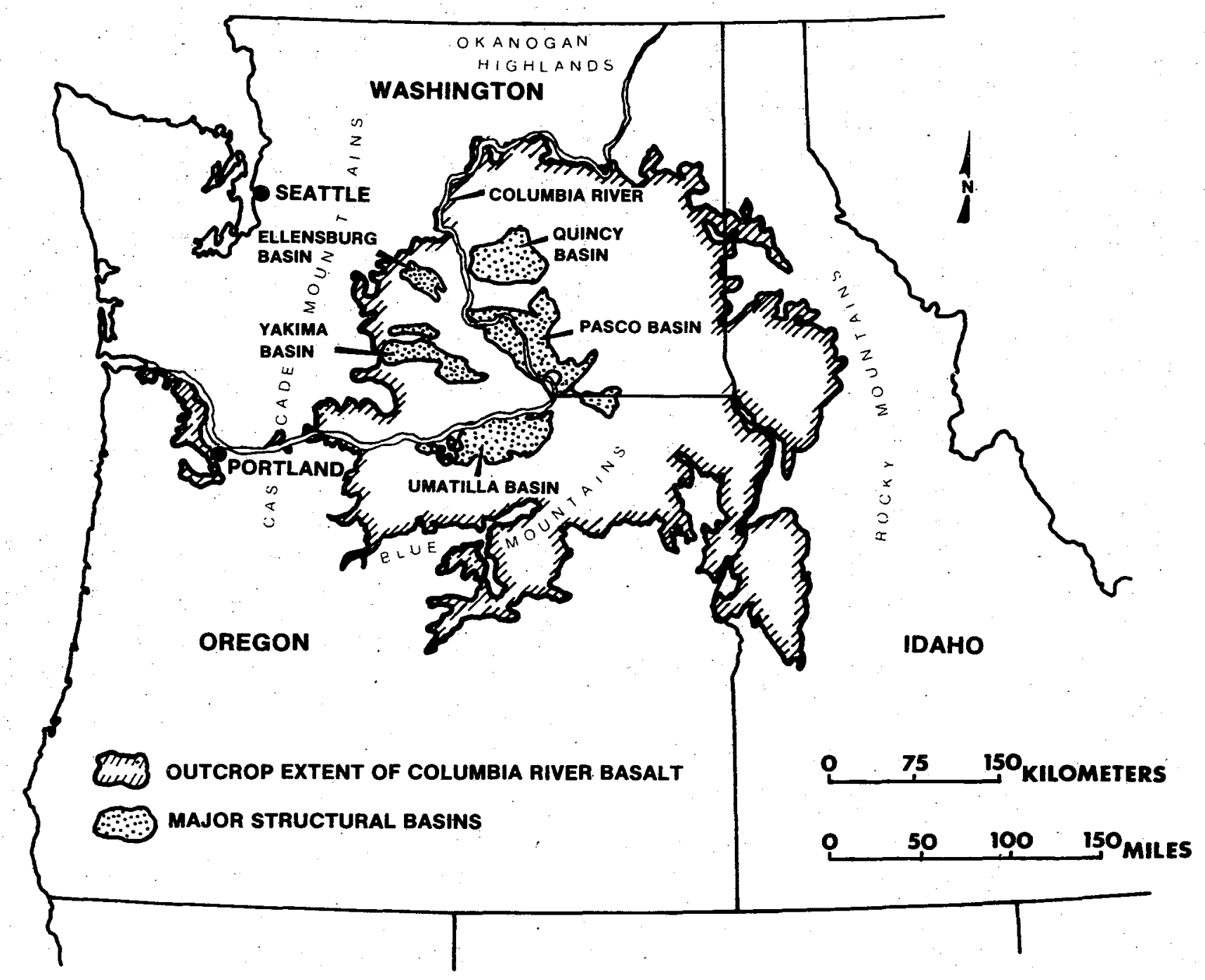

XBL 792-8312

Figure 1. Location map of the Columbia River Basalt (after Rockwell, 1977). 
tests on both multiple and single fractures; and a modular-type long-term monitoring system was recommended for development and installation in selected wells.

\section{FY 1978 ACCOMPLISHMENTS}

A. Hydrology Field Program

1. Equipment Development

During FY 1978 LBL designed down-hole instrumentation and packer systems for pressure, temperature and permeability testing. Pressure measurements at depths less than 3000 feet were made with a packer-mounted probe containing a single pressure and temperature sensor with no downhole packer release. A second tool was designed to operate at greater depths and do injection tests as well as pressure measurements. This tool included downhole solenoid valves to deflate packers and to bleed the test cavity of pressure pulse due to packer inflation, and an extra pressure transducer for monitoring packer pressure.

\section{Field Test Results}

Pressure testing was performed in Wells $D C-2, D C-6$, and $D C-8$ and permeabilities were estimated from artesian flow in DC-6. Figure 2 shows the location of these wells within the Hanford reservation.

\section{a. We11-DC-2}

We11 DC-2 is a 3300 foot deep hole drilled about 40 feet from We11 DC-1, a 5661 foot hole. Five standpipe plezometers were installed in DC-1 in 1972 and water levels have since been measured periodically.

Pressure measurements were made in 11 zones in DC-2 between depths 2269 feet and 3273 feet. The LBL test data, shown on Figure 3, appear to indicate that the vertical component of hydraulic gradient is sharply downward over the Interval tested. Comparison with open hole data, however, showed that a close correlation exists between the falling open hole head and the test zone measurements. This influence is thought to result from either vertical circulation of water through the formation or from residual effects of formation prepressurization which occurred when the well was filled for cleaning prior to testing. The tests were continued until the effects of the packer inflation pulse was essentialiy dissipated. However, time constraints did not permit the longer-term testing periods that would have been required for 


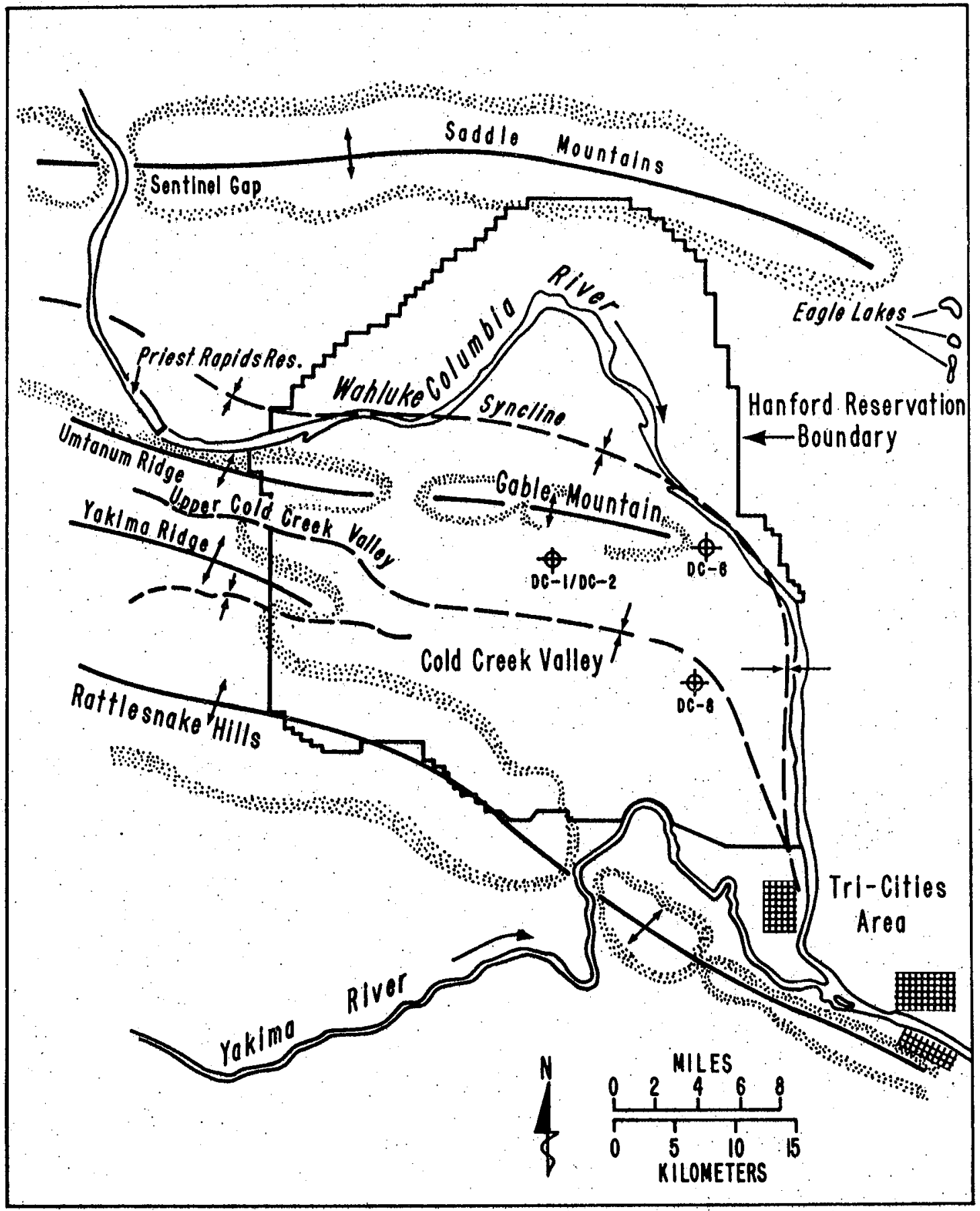

$X B L 7810-2108 B$

Figure 2. The Pasco Basin. 


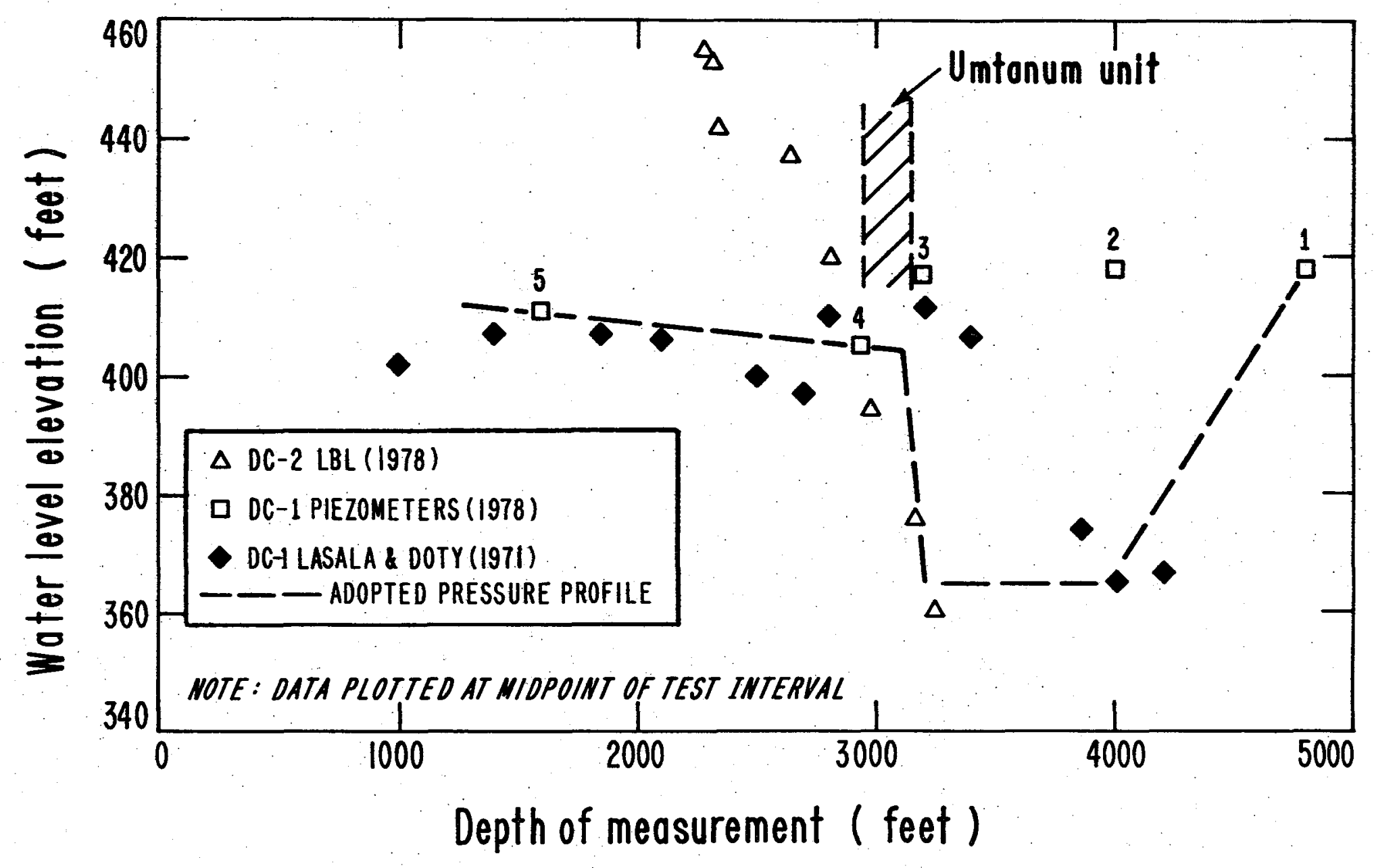

$X B L 7810-2109 A$

Figure 3. Pressure measurements in Vells DC-1 and DC-2. 
complete dissipation of the overpressure induced by packer inflation and by well cleaning in the lower permeabllity test zones. Increased testing times and increased sophistication of test equipment will be required to determine the degree to which residual effects of wellbore pressurization and the influence of vertical permeability affect test results in Well DC-2. The open hole water level in $\mathrm{DC}-2$ fell throughout the test perfod and was at an elevation of about 360 feet when the tests were concluded. This indicates that: (1) the minimum natural formation head within the open part of DC-2 is equal to or less than 360 feet elevation; and (2) this minimum head probably occurs below the Umtanum Unit. Pressure measurements made by La Sala and Doty in Well DC-1 before the piezometers were installed (1971), and piezometer levels in DC-1 at the time of testing in DC-2 are also shown on Figure 3. Based upon these data and upon observed dynamic changes in DC-1 due to swabbing in $D C-2$, it may be concluded that:

(1) Piezometer 2 and 3 readings are erroneously high because of vertical flow through leaks in the cement seals in Well DC-1 from a high pressure zone deeper than piezometer 2.

(2) The true formation pressure head elevation at the depth of piezometers 2 and 3 is on the order of 360 . feet.

(3) Piezometers 4 and 5 appear to be adequately isolated from the rest of the well.

(4) A downward pressure gradient apparently exists from at least the depth of plezometer 5 (2000 feet) through piezometers 4 and 3 to at least the depth of plezometer 2 (4000 feet), passing through the Umtanum Unit.

(5) An upward pressure gradient apparently extsts from at least the depth of piezometer 1 (4800 feet) to approximately the depth of piezometer 2 (4000 feet).

(6) The Umtanum Unit appears to be acting as a partial barrier to vertical flow.

b. We11 DC-8

Pressure testing was performed in Well DC-8 at nine zones between depths 1710 feet and 2700 feet with a constant packer interval of 30 feet. Open hole measurements were made immediately prior to packer inflation and subsequent to packer deflation. Filling of the wellbore during testing resulted in considerable variations in open hole water level during the early part of 
the testing period. The lowest water elevation recorded during the test period was an open hole head elevation of 413 feet. This measurement indicates that the formation pressure head within some part of the open portion of the well is at least as 1 ow as 413 feet. Data collected in DC- 8 is shown in Figure 5.

The tests generally appear to be less influenced by open hole pressure than in $\mathrm{DC}-2$, perhaps indicating a lower vertical permeability at Well DC-8. A downward gradient was measured within the depth range $1500-2100$ feet. Based upon extrapolation of this gradient, the minimum pressure head of 413 feet would occur at a depth of about 2300 feet.

c. We11 DC-6

We11 DC-6 is artesian and at the time of testing was flowing at a rate of about 17 gallons per minute. The first artesian zone was encountered during drilling in March 1978 between 2300 and 2710 feet, and additional artesian flows were encountered as the hole was deepened.

Water pressures were measured in 15 zones between 2240 and 4336 feet of depth. Artesian discharge from the well was measured in 12 zones between 2483 and 4336 feet, and permeabilities were computed for these zones. The groundwater pressure, flow, and permeability data are shown in Figure 4.

All pressure measurements indicate artesian heads above the elevation of the hole collar, hence all test zones are contributing to the flow from the hole. Between depths of 2240 and 3055 feet the pressure heads average about 450 feet. The scatter in the data does not allow reliable definition of either an upward or a downward gradient. Below 3055 feet heads decline reaching a local minimum elevation of approximately 430 feet in a water producing zone at about 3700 feet of depth. An increase in head below 3700 feet is shown by the head of 466 feet recorded for the zone between 3802 and 4336 feet. There is generally good agreement between the heads measured by Lynes and W. K. Summers Associates in March, 1978 and the values determined by LBL (see Figure 4A).

The most prolific flowing zone yielded about $70 \%$ of the total flow and occurs between depths of 3692 feet and 3.769 feet as shown on Figure 4B. This zone was logged as a highly altered flow breccla. Flows on the order of one gallon per minute were also measured from similar breccia zones between 3650 feet and 3692 . feet.

Permeabilities were estimated using the assumption of steady radial 


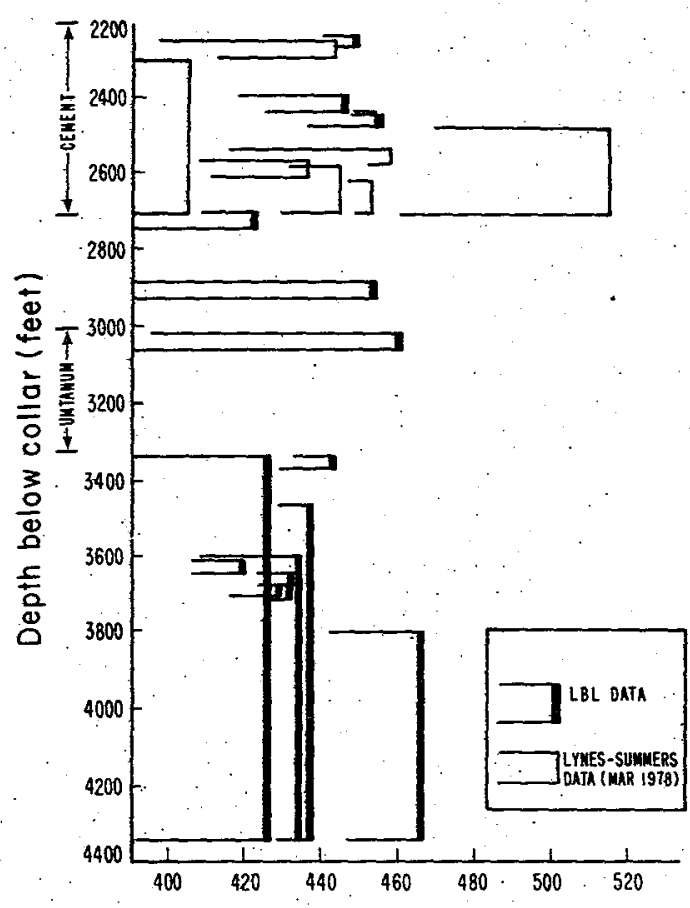

A. Head ( feet $)($ datum $=$ mean sea level)

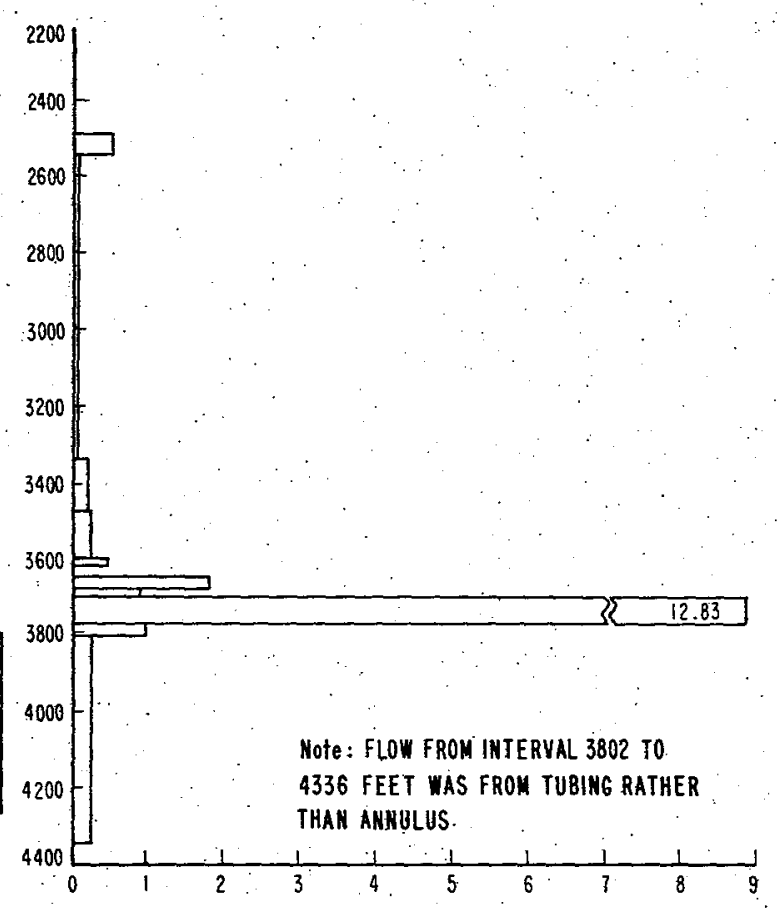

B. Flow $(g p m)$

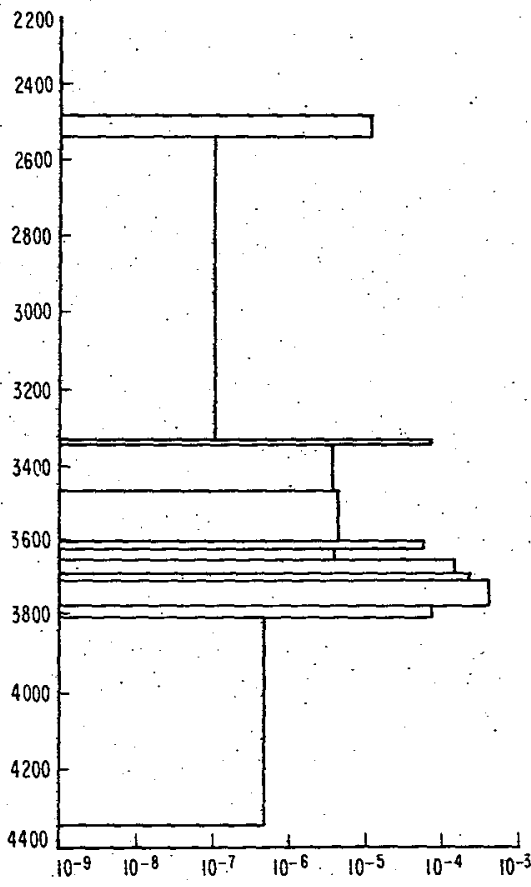

C. Permeability $(\mathrm{cm} / \mathrm{sec})$

XBL $792-7374 A$

Figure 4. Water heads, flow rates and permeabilities in Well DC-6. 


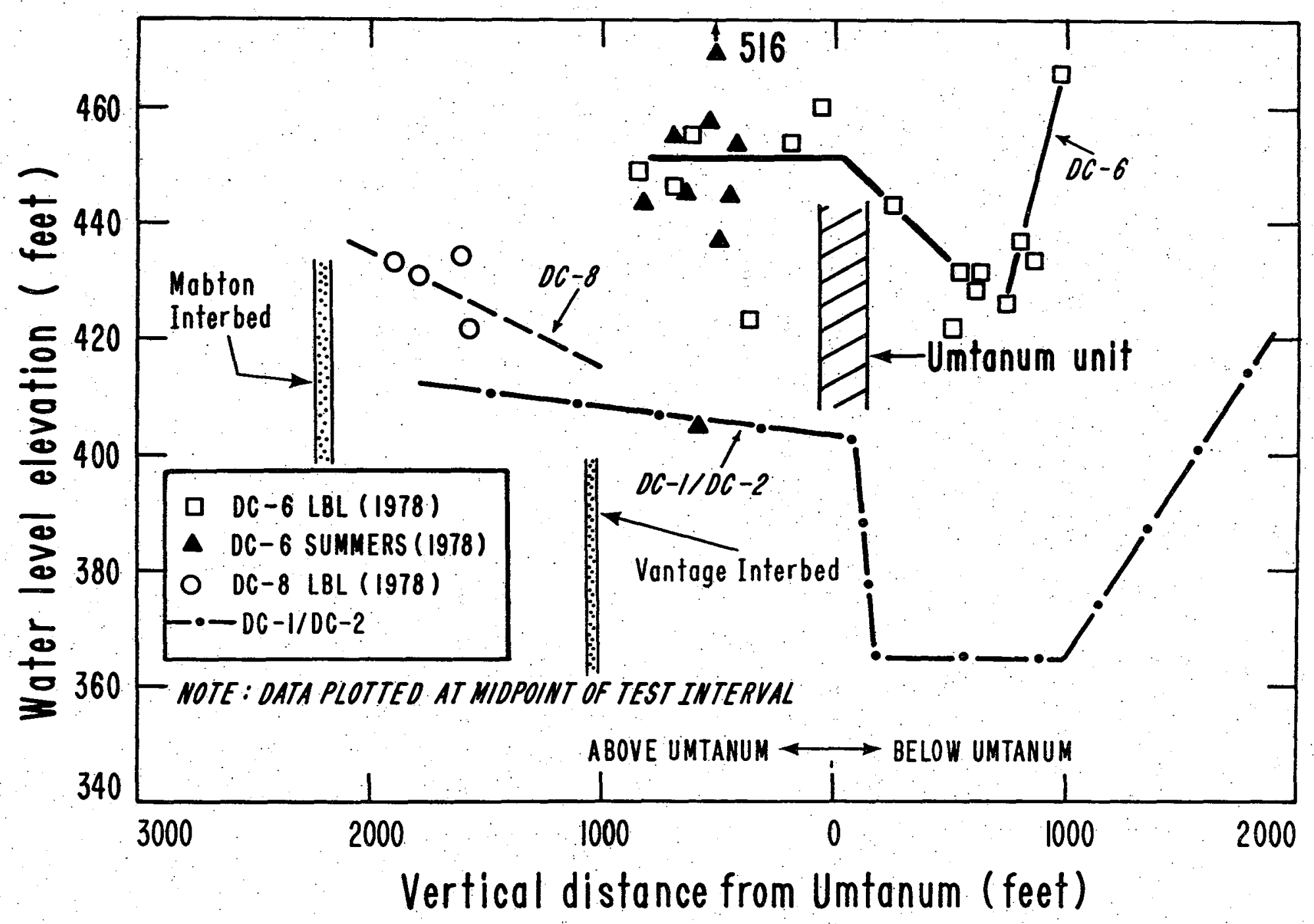

$X B L 7810-2110 B$

Figure 5. Summary of pressure measurements. 
flow. The results are shown in Figure $4 \mathrm{C}$ and represent the average for the zone tested. The largest permeabllities were on the order of $10^{-4} \mathrm{~cm} / \mathrm{sec}$, measured in the zone between 3650 and 3800 feet. This zone is about 400 feet bel ow the Umtanum Unit. The lowest average permeabilities were on the order of $10^{-7} \mathrm{~cm} / \mathrm{sec}$, measured in and above the Umtanum Unit.

d. Comparison of Pressure Results

The results of pressure measurements in Wells DC-1/DC-2, DC-6; and DC-8 are shown in relation to stratigraphy on Figure 5. These data show a downward gradient between the Vantage interbed and the Umtanum Unit in $\mathrm{DC}-1 / \mathrm{DC}-2$. The gradient is poorly defined, however, in the same zone in DC-6. DC-8 shows a downward gradient between the Mabton and the Vantage interbeds. Head elevations reach a 1 ocal minimum in $D C-1 / D C-2$ and $D C-6$ about 300 feet below the bottom of the Umtanum and there is evidence that gradients may be upward below that depth. The low pressure zone encountered below the Umtanum would act as a drain for any vertical flow converging upon 1 t, thus the recharge and discharge areas of this zone are of great interest.

Pressure data for the zone Immediately below the Umtanum is presently avaflable only for Wells $\mathrm{DC}-1 / \mathrm{DC}-2$ and $\mathrm{DC}-6$. We11s $\mathrm{DC}-1 / \mathrm{DC}-2$ are in the northern flank of Cold Creek Valley syncline, formed between Gable Mountain anticline to the north and Rattlesnake Hills anticline to the southwest (see) Figure 2). The water level elevations measured in and below the Umtanum in $\mathrm{DC}-1 / \mathrm{DC}-2$ range from 395 to 362 feet. The only part of the Pasco Basin with lower elevations which would serve as a discharge area is the Columbia River bed and adjacent lands from the Tri-Cities area to Wallula Gap. The most likely flow path from $\mathrm{DC}-1 / \mathrm{DC}-2$ to this discharge area is through Cold Creek. Valley.

Pressure head elevations measured in DC-6 in and bel ow the Umtanum range from 421 to 466 feet. The relatively low pressures measured in the deep basalts in Cold Creek Valley and the higher pressures measured in DC-6 suggest higher water tables to the north and east of DC-6. The most 11kely source of recharge for these high heads is the Columbla River from Sentinel Gap to Priest Rapids Reservoir. The basalt units beneath the Umtanum are at or near the ground surface in this area, and the river is a source of abundant volumes of water. The most 11kely flowpath to Well DC-6 from this potential recharge area would be along the Wahluke syncline, a structural and topographic valley between the Gable Mountain-Umtanum Ridge anticline and the 
Saddle Mountain anticline. Other potential recharge areas, such as the Saddle Mountains or the Eagle Lakes-Scooteney Reservoir area to the northeast of DC-6, are either relatively dry or do not have outcrops of the Umtanum and underlying units. They are therefore less likely to be primary recharge areas.

The pressure data and recharge hypotheses for the deep basalts at DC- 6 imply that water pressures throughout the Wahluke syncline are substantially higher than those measured in Cold Creek Valley at Well DC-2. Such a difference would suggest the existence of a barrier to groundwater flow in the general vicinity of the Gable Mountain-Umtanum Ridge anticline. This hypothesis is supported by a lack of likely recharge areas for the Umtanum and underlying units in the vicinfty of Cold Creek Valley. Gable Mountain on the north side of the valley is 1 ow and provides essentially no recharge. The Yakima Ridge area to the east of the valley and the Rattlesnake Hills to the south rise to elevations of several thousand feet, but 1 ike the Saddle Mountains, are relatively dry. Further, the Umtanum Unit is at 1 east $1000 \mathrm{feet}$ deep in all of these areas. Some underflow in the deep basalts may be occurring through structural valleys paralleling Yakima Ridge, but as noted by Newc omb and others (1972, p. 32), the high heads found in a number of deep artesian wells near the western boundary of the Hanford Reservation suggest the presence of a second flow barrier cutting across these structural valleys. The presence of relatively high heads at Juniper Springs and Rattlesnake Spring versus the relatively 1 ow heads measured in DC-1/DC-2 supports the assumption of an additional flow barrier. The possible existence of these flow barriers is of significant interest in repository siting and should be fur ther investigated.

e. Comparis on of F1 ow Data

Radioactive tracer and temperature logs in Well DC-1 have Indicated three zones of relatively high permeability at depths of $3228-3234$ feet, 3972 - 3980 feet, and 4824 - 4854 feet. The average permeability of these zones is $9.4 \times 10^{-4} \mathrm{~cm} / \mathrm{sec}$. The first two of these zones are 50 feet and 794 feet below the bottom of the Umtanum Unit.

In. Wel1 DC-6 the major flowing zone was determined to have a permeability greater than $10^{-4} \mathrm{~cm} / \mathrm{sec}$ and occurs between depths of 3650 and $3700 \mathrm{feet}$, which is 442 feet below the Umtanum. There are likely to be, in addition, other zones with permeabilities greater than $10^{-6} \mathrm{~cm} / \mathrm{sec}$ between the bottom 
of the Umtanum and the high permeability zone at $3650 \mathrm{feet}$, but the large spacing between packer settings in the LBL flow tests did not allow better definition of the exact location of these higher permeability zones.

Comparing the data for the two wells, it is clear that the most permeable zones encountered are below the Umtanum, but these zones do not appear to occur at the same stratigraphic levels relative to the Umtanum Unit in the two wells. The similarity of geochemical stratigraphy for the two holes suggests that these permeable zones may be occurring at different basalt flow contacts. The extent to which these zones may be hydraulically interconnected through a continuous weathered horizon, through faults, or through primary fractures will be important to radionuclide migration from a repository and should be the subject of further studies.

\section{B. Pasco Basin Modeling}

The Pasco Basin hydrology modeling effort had three products. The first was a literature survey. The second was a recomendation for a well drilling and testing program. The third was a series of numertcal solutions for use in the design of hydrologic field tests such as pump tests and leaky aquifer tests where wellbore storage is significant.

\section{Literature Survey for Regional Flow System}

The literature survey was undertaken to help define such flow model inputs as boundary conditions, inftial conditions, geometry as defined by structural geology, and material properties. The system boundaries are apparently complex and trregular. The groundwater flow system is further complicated by numerous folds and faults and basalt flows of variable continuity. Although primary porosity may be of importance locally, by and large the flow paths are governed by fractures of widely varfable pattern (horizontal, columnar, etc.) and spacing. The system is probably characterized by time dependent boundary conditions and a variable, three dimensional. distribution of fluid potentials.

Such input data will always be accompanied by uncertainty and hence the simulation results will also be accompanied by significant uncertainties. A limitation of the current LBL models is that they a11 are intrinsically deterministic. Since the flow system parameters cannot be known with certainty, confidence limits on the potential range of system response must be 
provided for the decision-making process. An important capability which would improve the LBL models would therefore be the accomodation of statisistically expressed input parameters and the statistical expression of output parameters indicating the distribution of possible system responses. Further work on the development of such models is recommended to permit adequate risk assessment of repository safety.

\section{Recommended Well Drilling and Testing Program}

Based on the results of the field work, the literature survey, and the input requirements, a well drilling and testing program was developed for further study of the Pasco Basin. In order to achieve the immediate objective of providing an overview of the regional flow system, six first stage wells, DC-12 through DC-17, were proposed (Figure 6). These wells, when combined with existing wells, are designed to provide sufficient information to indicate on a gross scale the origin, flow paths, velocities, and disposition of groundwater within the basin.

Well. DC-12 is in the center of the basin. This well would provide data for determining gradients in several directions within the basin. We11 DC-13 is in the "horn" of the Columbia River. This well would help to determine the hydrologic significance of the Saddle Mountains boundary and the influence of the Columbia River on the deep flow system. It would also provide an important data point in the Wahluke syncline. The role of the Rattlesnake Hills as a recharge zone in the basin needs to be investigated. We11 DC-14 would provide information on the extent of this recharge and the possible existence of perched waters. The southwestern boundary of the basin can also be examined.

Well. DC-15 examines the extent of recharge from the Sentinel Gap area. The area is important because basalt flows which lie deep under the center of the Basin crop out at Sentinel Gap. This well in conjunction with DC-4 will also help to determine the direction of deep groundwater flow between Cold Creek Valley and the Columbia River Valley. In conjunction with DC-13, this well will enable an examination of deep flow systems along the Wahluke Syncline.

If the rough analysis of groundwater flow patterns seems favorable for siting a repository, these wells will provide a basis for locating second stage wells which may be necessary for a more detailed analysis of the flow sys tem. 


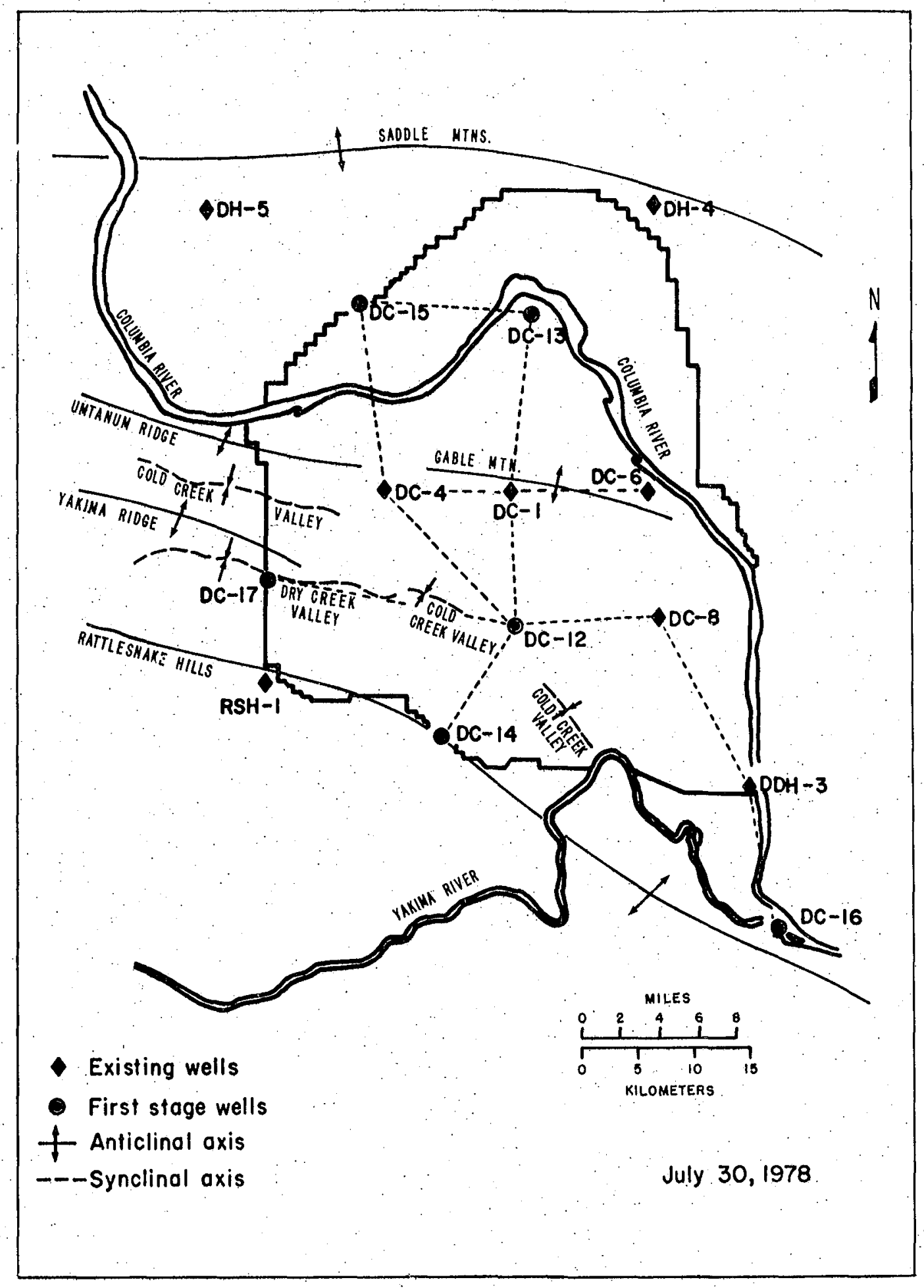

XBL . 794-9411

Figure 6. Proposed first stage wells. 


\section{Wellbore Storage Effects}

Pumping tests were planned for several wells on the Reservation and analyses were made of two anticlpated wellbore storage problems. The first problem was to describe the response of an observation well in a pumping test where wellbore storage was significant. The second problem was to see how wellbore storage would affect the data collected in a leaky aquifer test. The LBL groundwater flow program TERZAGHI was used for both problems.

a. Observation well response with wellbore storage

Dimensionless drawdown curves were obtained for values of dimensionless storage parameter, $\alpha$, of $10^{-1}, 10^{-2}, 10^{-3}, 10^{-4}$, and $10^{-5}$. A sample is shown in Figure 7. The curves approach the Theis solution with decreases in radius of the well and increase in $\alpha$. The time necessary to obtain a response in the observation well increases with an increase in wellbore storage effect.

b. Leaky aquifer response with wellbore storage

Fifteen different cases were analyzed for times up to 100 days, comprising three different pumping well radii $(.05, .09$ and $.1125 \mathrm{~m})$ and five different values of $\alpha\left(10^{-1}, 10^{-2}, 10^{-3}, 10^{-4}\right.$, and $\left.10^{-5}\right)$. A sample of results is plotted in Figure 8 showing the ratio of drawdown in the aquitard $\left(s^{\prime}\right)$ to drawdown in the aquifer (s) as a function of wellbore radius. Observation well drawdown with wellbore storage can be as little as half the drawdown predicted without wellbore storage.

Figure 9 shows the time it would take to get a drawdown, $s^{\prime}$, in an aquitard 9.0 meters from a pumping well and 0.5 meters from an aquifer. The parameters and geometry used are typical of what might be found in the Pasco Basin. At least 15 days of pumping would be required to get any measurable response in the aquitard for these conditions. This model could be used for iwe11 test analysis by developing a set of type curves for any specific well radius and distance to an observation well. 


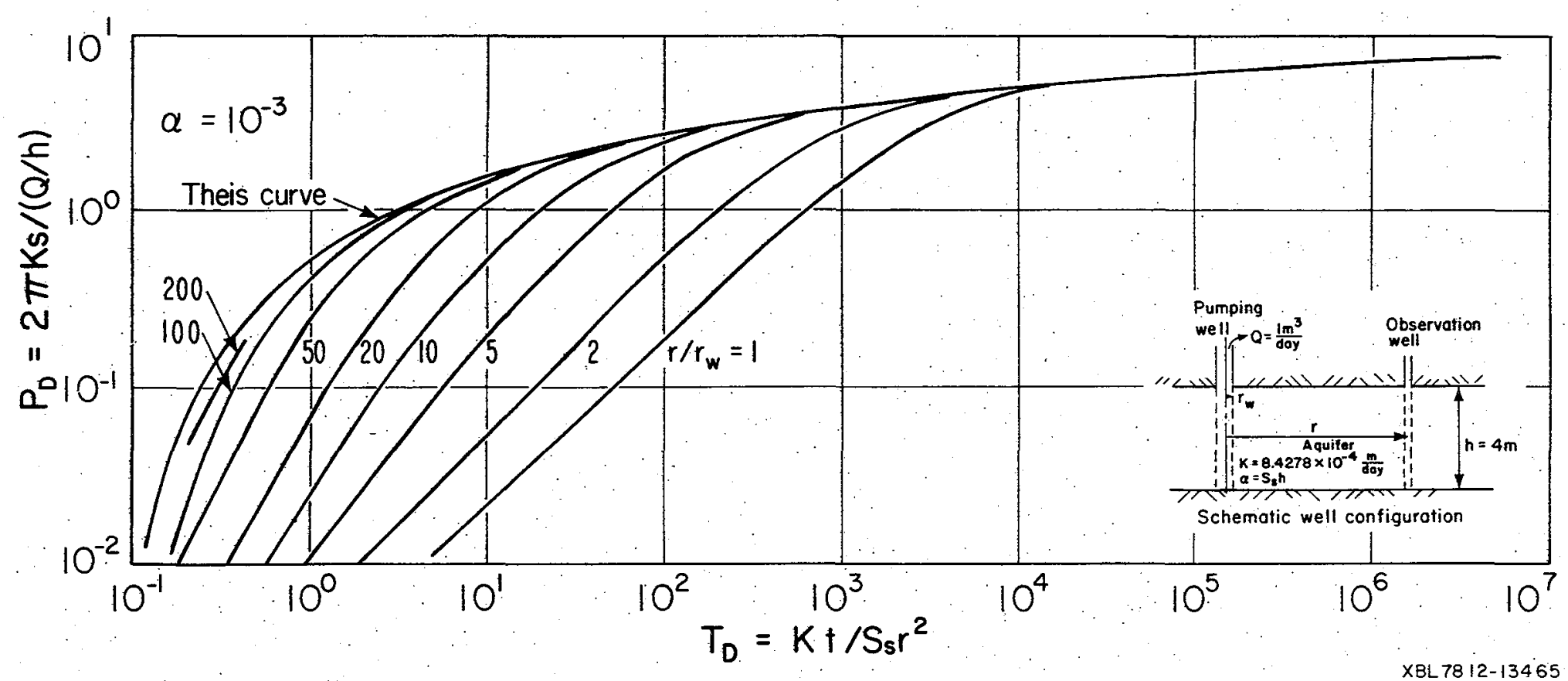

Figure 7. Drawdown in an observation well with wellbore storage in the pumping well, $\alpha=10^{-3}$. 


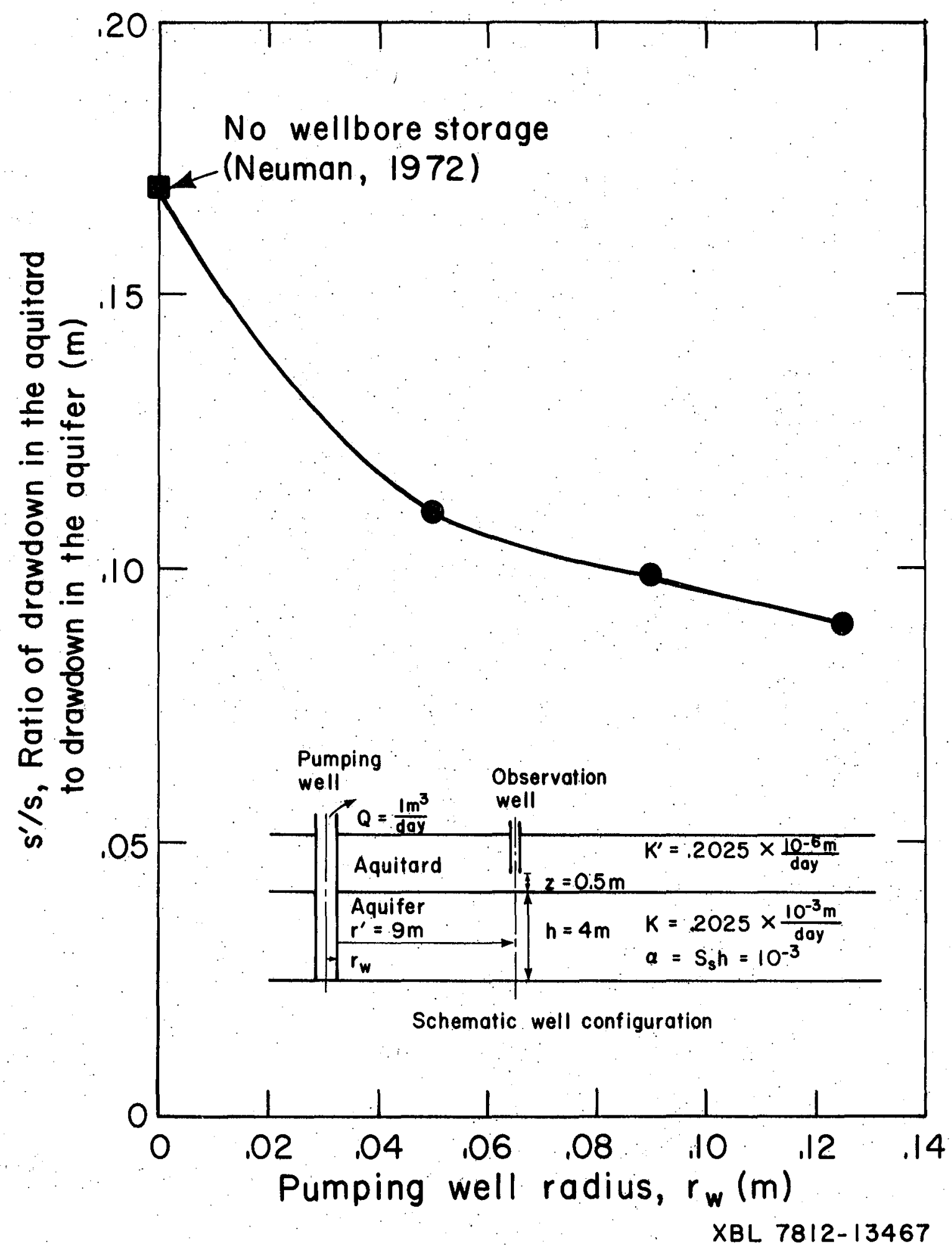

Figure 8. Ratio of drawdown in the aquitard to drawdown in the aquifer, $\mathrm{s}^{1} / \mathrm{s}$, at $\mathrm{r}=9 \mathrm{~m}$, as a function of pumping well radius at $t=100$ days, $\alpha=10^{-3}$. 


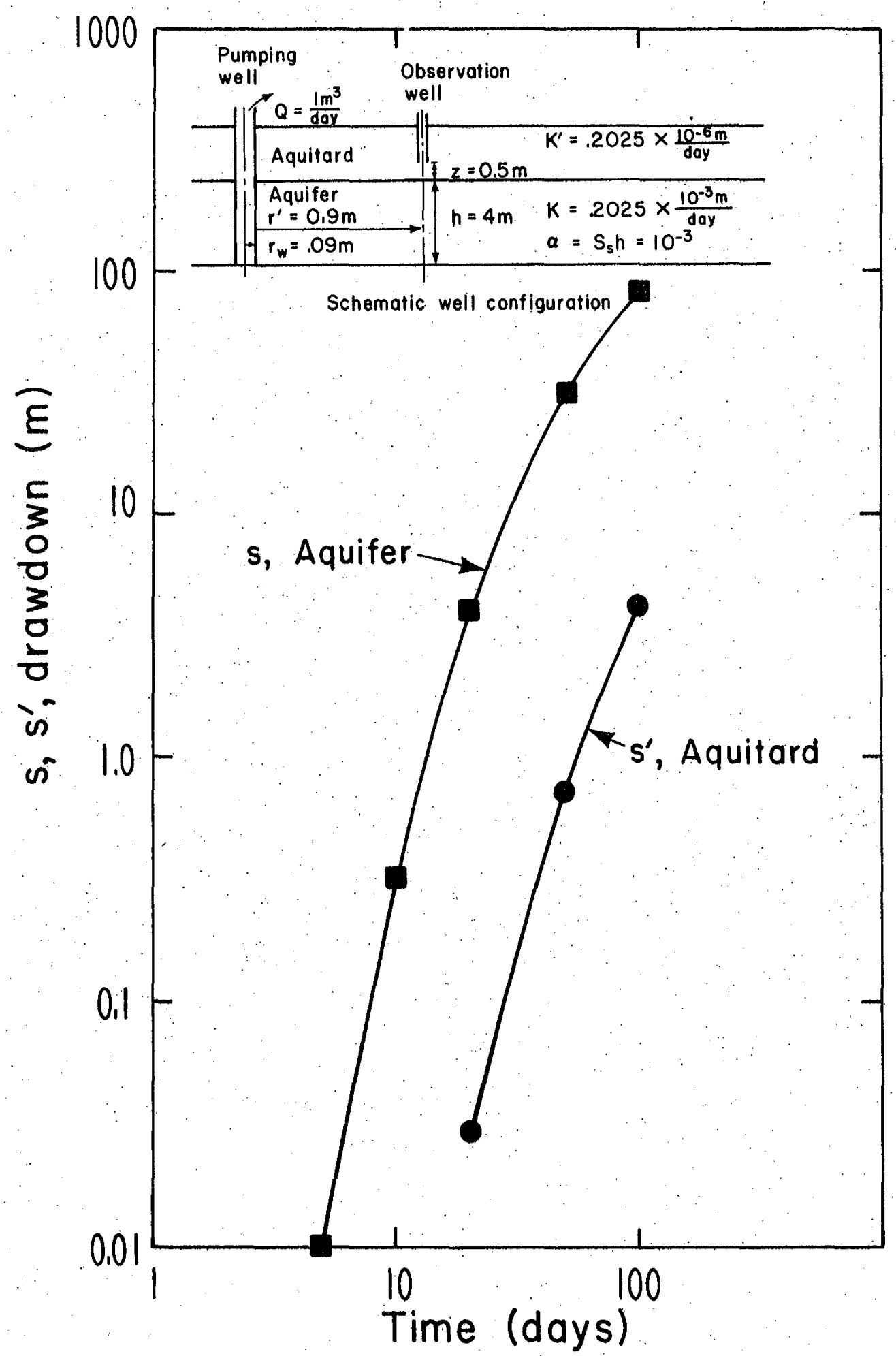

XBL 7812-13469

Figure 9. Drawdown as a function of time for $\alpha=10^{-3}, r_{\mathrm{w}}=.09 \mathrm{~m}$. 


\section{Groundwater Chemistry Program \\ 1. Introduction}

The sampling and analysis of groundwaters for the Pasco Basin was Initiated as part of the LBI Hanford Waste Isolation Project.. It was planned to perform comprehensive chemical and isotopic analyses of 36 deep well samples, 20 spring samples and 9 duplicates samples. The chemical analyses were to provide information that would permit determination of the source, history, and age of the waters of the Pasco Basin. This information, when used in conjunction with hydrologic data and regional hydrologic simulations of groundwater movement in the Pasco Basin, was expected to provide the basis for predicting the rate and type of chemical evolution of the groundwaters during flow. Such an evaluation is a necessary prerequisite for quantitative predictions of radionuclide migration in the same environment.

\section{Previous Groundwater Chemistry Studies}

Earlier drilling activities in the Pasco Basin by Fentx and Scisson Inc. indicated a minimum of three zones between 2888 feet and 3392 feet that appeared to justify further investigation as locations for mined caverns. Aquifers adjacent to these zones were therefore considered as the prime target for investigation. Previous studies of groundwater chemistry in the Pasco Basin were $f e w$ in number. The evidence given by these studies and supported by the chemical analyses is that sampling deep well waters without contamination from extraneous sources would be both difficult and time consuming. 3. 1978 Activities

The chemical analyses planned for the groundwater samples included all major cationic and anionic species as well as trace elements, gas analyses, and on-site measurements of those species or properties that were likely to change during transport. The purpose of these analyses was to allow comparison with the compositions and theromdynamic stabilites of coexisting alteration products, to make internal checks on the validity of the analyses, and to permit estimation of the sources and the relative ages of the groundwaters. Trace elements were to be tested for their value as tracers for given aquifer waters or horizons.

A number of stable and radiolsotopic analyses were also planned including those for $\mathrm{D} / \mathrm{H}, 18_{0} / 16_{\mathrm{O}},{ }^{13} \mathrm{C} / 12^{\mathrm{C}},{ }^{34} \mathrm{~s} /{ }^{32} \mathrm{~s}, 3_{\mathrm{H}},{ }^{14} \mathrm{C},{ }^{36} \mathrm{Cl},{ }^{222} \mathrm{Rn},{ }^{22} 6_{\mathrm{Ra}}$, and $234 \mathrm{U} / 238 \mathrm{U}$. Each of these isotopic analyses contributes to an interpretation of the source, temperature, history, or age of the groundwater. The 
measurement of the age of groundwater is difficult to accomplish or interpret. Consequently, part of the study was directed towards elucldation or clarification of the problem associated with the utilization of ${ }^{36} \mathrm{C} 1$ and ${ }^{234} \mathrm{U} / 238_{\mathrm{U}}$ as tools for dating groundwaters.

LBL staff recognized the need for adequate laboratory services readily accessible from the sampling site, in order to perform analyses for fugitive components, separation procedures for isotopic analyses, and the filtration of samples. A mobile field laboratory was therefore designed and constructed to perform all necessary. on site analyses and sample preparation. An $8 \times 20$ foot box trailer was leased for this purpose and adequate facilities for two chemists were provided. The mobile laboratory proved to be very satisfactory from the functional standpoint, but the need for a tow truck to move it and 1ack of intrinsic strength were disadvantages.

The complex sampling requirements for each of the several analytical and isotopic techniques involved in the study necessitated standard operating procedures for Quality Assurance documentation. These procedures became the focal point of organizing and finding the latest and most desirable methods for the sampling, treatment, and packaging of groundwater. Several meetings were held with leading isotope and chemical analysts in order to bridge the gap between analytical expertise and field sampling methodology. These meetings, combined with an exhaustive 1iterature survey of groundwater sampling, resulted in the drafting of Field operating Procedures for the groundwater chemistry part of the Hanford Waste Isolation Project. This document includes procedures for both well and spring sampling. Improvements were incorporated as fleld experience was gained.

On January 30, 1978 a meeting was held between the staff of Rockwe11 Hanford Operations, LBL, and other interested parties, to develop the fleld program. Between then and June 14, 1978, when swabbing of DC-2 started, isotope and analytical chemists were committed to provide support for the project, Quality Assurance documentation was prepared, and the moblle field laboratory was designed, constructed and equipped. Sampling and refinement of field procedures continued with occasional interruptions until August 16, 1978, when field work was terminated.

Groundwater samples from deep wells were obtalned by swabbing, as no other technique had been developed that would permit recovery of large samples from the depths specified in the narrow diameter wells available for 
sampling. Only We1l DC-2 was sampled, from the zone between 3243 and 3273 feet. In the short time avallable for sampling, it was not possible to pump sufficient water to obtain a sample free of contamination.

Springs were identifled from topographic maps, and chosen following discussion with Rockwell geologists. Only those springs were sampled that issued directly from geologic formations. A total of four springs were sampled in the time available. Access to the spring sites was difficult and required 4-wheel drive vehicles. Three flowing artesian wells (DC-6, Ford and McGee) and the Columbia River were also sampled using similar techniques to those developed for spring samples. Chemical and isotopic analyses were performed on the nine samples collected. The chemfcal analyses covered most of the elements and aqueous spectes or Iginally specifled. Analyses of some minor components were not performed, primarily because the project was terminated before the work could be completed. However, all major components were analyzed. In many cases different analytical methods were used to measure the same component, thus providing checks on the accuracy of the values obtained. Cation/anion balances were performed on major components of the solutions using the results of a given analytical method for each element that gave the greatest accuracy for that element. In all cases except one, the discrepancy between total cation and anion equivalents was less than $5 \%$ of the sum.

The major components and some important minor components in solution were used as input to the distribution of species stage of the FASTPATH code, and checks made on the internal consistency of $\mathrm{pH}$, alkalinity, Eh, sulfide/ sulfate and $\mathrm{CO}_{3}{ }^{2-} / \mathrm{HCO}_{3}-$ pairs. With minor exceptions, results were good. Isotopic analyses for $\mathrm{D} / \mathrm{H}, 13_{\mathrm{C}} / 12^{\mathrm{C}}, 18_{0} / 16_{0}$, and $3_{\mathrm{H}}$ were also determined. However, ${ }^{14} \mathrm{C}$ analyses were not performed owing to inftial problems with the procedure used to separate carbonate from solutions.

Analytical development of isotope measurement techniques using the 88inch cyclotron at LBL demonstrated the feasibility of measuring ${ }^{14} \mathrm{C}$ in $\mathrm{CO}_{2}$ evolved from one liter samples. The detection of ${ }^{36} \mathrm{Cl}$ was also attempted, and a limit of $10^{-12}$ for ${ }^{36} \mathrm{C} 1 /{ }^{35} \mathrm{C} 1$ was achieved with possibilities of improvement using a new ion source. Measurement of the ${ }^{234} \mathrm{U} /{ }^{238_{\mathrm{U}}} \mathrm{U}$ ratios on the water samples is continuing using a 5 foot radius high-precision mass spectrometer. A precision of about $2 \%$. is adequate for the ${ }^{234} \mathrm{U} /{ }^{238} \mathrm{U}$ ratio and can be achieved. 


\section{Conclusions and Recommendations}

An evaluation of the chemical analyses in terms of thetr origin, history, and age are not possible owing to the small number of samples taken, the incomplete isotopic analyses, and the diversity of regimes from which the samples were obtained. No spatial relations between samples can be worked out until more samples have been obtained and analyzed, over more horizons, and over a greater areal extent of the Pasco Basin. However, the work done to date leads to the following recommendations.

1. Because of the low concentration of many important components in the deep waters of the Pasco Basin, great care should be taken in avoiding contamination both during and after sampling.

2. Drilling methods that minimize contamination of aquifers should be used. .

3. On-site contamination monttoring should be developed using tracers incorporated in the drilling fluids.

4. All sources of contamination should be identified.

5. Downhole sampling devices should be designed and constructed that el iminate contamination from that source.

6. Collection procedures for carbonate samples for ${ }^{14} \mathrm{C}$ analysis should be improved.

7. Improved isotopic techniques requiring smaller sanples should continue to be developed; this applies particularly to ${ }^{14} \mathrm{C},{ }^{36} \mathrm{Cl}$, ${ }^{81} \mathrm{Kr}$ and ${ }^{234} \mathrm{U} / 238 \mathrm{U}$.

8. Discrepancies in species distribution based on alkalinity measurements and chemical analyses should be resolved.

9. More accurate methods of determining oxidation potential in groundwaters from Hanford should be developed.

10. A more sensitive technique for analyzing aluminum in solution should be developed, particularly in the presence of large amounts of fluoride ion.

11. Soluble organic components, and $\mathrm{Li}, \mathrm{B}, \mathrm{NH}_{4}{ }^{+}$, and $\mathrm{P}_{2} \mathrm{O}_{5}$ should be analyzed to determine their significance.

12. More sensitive gas detection and analytical techniques should be developed. 
D. Review of Hanford Well Logs

The work performed in 1978 consisted of a review of pre-existing well $\log$ data and data obtained during the year by other Rockwell subcontractors. The well logs at Hanford can be used in several ways to atd the hydrology program:

(1) to examine rock properties, such as porosity, density, and fracture character, on a continuous coverage basis;

(2) to delineate zones of fiuld flow;

(3) to correlate geologic units between wells.

Figure 10 demonstrates the response of four standard logs to the basalt in the 2800 - 3400-foot interval in Well DC-1. As porosity increases, all quantities measured by the four sondes deflect to the left. For example, the large deflection from 2950 to 3000 feet is an interbed of much higher porosity than the dense basalt below, from 3000 to 3180 feet. Currently, it is not possible to accurately quantify the porosity because all the sondes are calibrated for sedimentary sequences. Further work with the avallable logs and core could soon overcome this problem.

Figure 11 shows temperature $\operatorname{logs}$ and flow proflles from the entire 5000-foot length of hole DC-1. Breaks in the temperature gradient occur where fluid has left the wellbore and entered the formation, thereby cooling the rock below the temperature dictated by the geothermal gradient. These temperature breaks are confirmed by the flow profiles, which were obtained with the radioactive tracer technique. With this method the downward velocity of the borehole fluid is measured by injecting a tracer into the water column and detecting its transit time past detectors in the sonde. The abrupt drops in velocity occur where fluid leaves the wellbore and enters the formation. The obvious zones in Figure 11 were detected on several logs run at different times, confirming the validity of the methods.

In the course of the review it became clear that the hydrology program would be assisted by a greater effort in well $\log$ interpretation and a coordinated program in acquiring, new logs. Among the recommendations are:

o routinely obtain flow profiles in all new holes, with the spinner tool appearing to be the preferred method;

- establish a reliable method of quantifying the porosity in the basalt;

o composite the existing well logs and auxillary data onto base sheets;

- continue to pursue those 1 ogs, such as spectral gamma and magnetfc susceptibility, which promise correlative geological data among holes. 


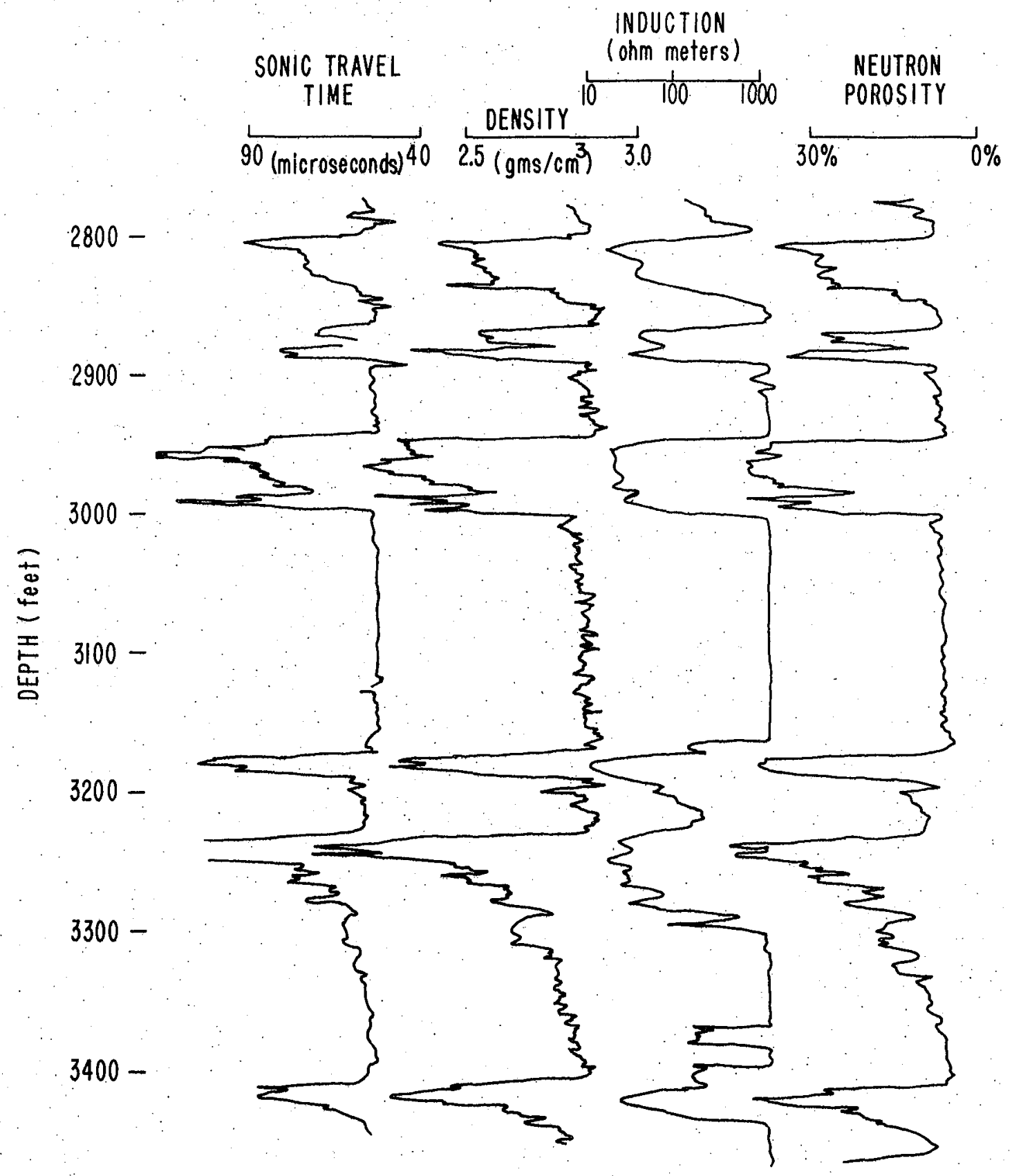

XBL $7811-12520$

Figure 10. Four porosity-type logs in Well DC-1. 


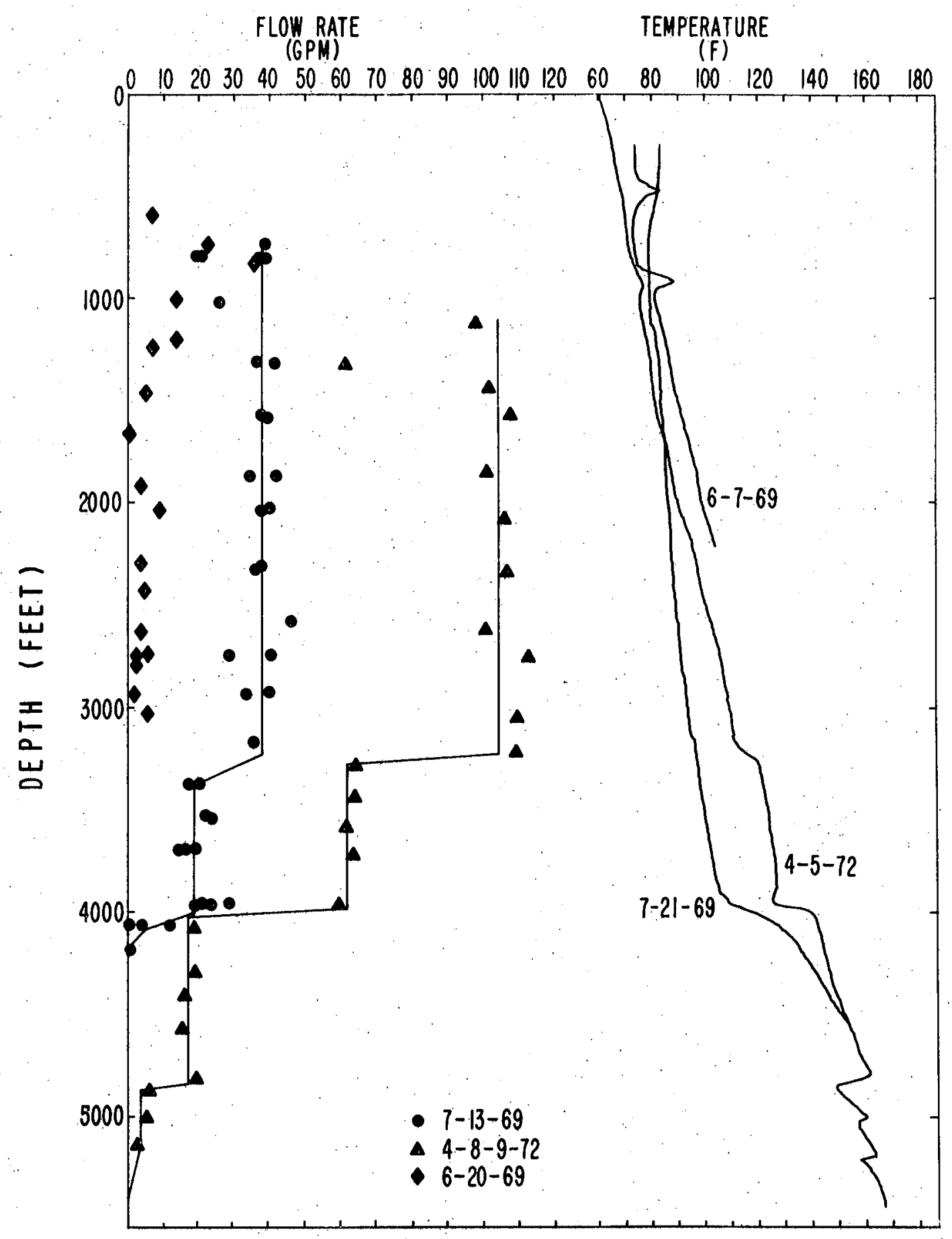

XBL 7811-12517A

Figure 1.1. Summary figure of anomalous flow zones in We11 DC-1. 


\section{REFERENCES}

La Sala, A. M., Jr., and G. C. Doty, 1971. Preliminary Evaluation of Hydrologic Factors Related to Radioactive Waste Storage in Basaltic Rocks at the Hanford Reservation. U.S. Geological Survey Open File Report.

Neuman, S.P., P.A. Witherspoon, 1972. Field determination of the hydrologic properties of leaky multiple aquifer systems, Water Resources Research, V. 8, no. 5, pp $12-84$, October 1972 .

Newcomb, R.C., J.R. Strand, and F.J. Frank, 1972. Geology and groundwater characteristics of the Hanford Reservation of the USAEC, Washington, USGS Prof. Paper 717.

Rockwe11 International, Department of Waste Isolation, 197\%. Basalt Waste Isolation Program Annual Report. RHO-ST-9. 

